\title{
Investigation of Students' Psychology: The Relationship among Students' Attitudes, Persistence, Creativity, and Tolerance toward Natural Science Subjects
}

\author{
Darmaji, Astalini, Dwi Agus Kurniawan*, Nirmala Sari, Orin Hidayusa Wiza, Yolanda Eka Putri \\ Faculty of Teaching and Education, Universitas Jambi, Indonesia
}

Received December 24, 2019; Revised February 27, 2020; Accepted March 12, 2020

Copyright $\odot 2020$ by authors, all rights reserved. Authors agree that this article remains permanently open access under the terms of the Creative Commons Attribution License 4.0 International License

\begin{abstract}
This study aims to describe the relationship between students' attitudes among persistence, creativity, and tolerance in science subjects in Muaro Jambi Middle School, Jambi City Middle School, and Batanghari Regency Middle School. The research design used was quantitative associated with a correlation design. The data collection technique used is total sampling. The research subjects were 767 students. The research instruments used were closed questionnaires consisting of 54 statements of attitude questionnaire, persistence, questionnaire of 30 statements, creativity questionnaire as many as 31 statements and tolerance questionnaires as many as 32 statements. The data analysis technique used is descriptive statistics and inferential statistics. Based on the results of the correlation test on the four variables obtained, a relationship between students' attitudes toward persistence, creativity, and tolerance in science subjects in the Middle School in Muaro Jambi Regency is with a sufficient category. Then students' attitudes toward persistence, creativity, and tolerance in science subjects in Jambi City Junior High School have a positive relationship with a strong category. Likewise, students' attitudes toward persistence, creativity, and tolerance in science subjects in the Batanghari Regency Middle School have a positive relationship with a strong category.
\end{abstract}

Keywords Persistence, Creativity, Tolerance, Attitude

\section{Introduction}

A country that can develop and keep up with the times must have productive and competitive human resources which will become the nation's next generation. In an effort to form a quality generation of the nation, the quality of education in Indonesia must also be improved, because education is the main key for a nation in opening the horizons of the world. Education is not only a medium to pass on culture to the next generation, but also has a better direction, so that later generations of nations will grow and develop and benefit the future of the nation $[1,2]$. Education as a tool for social change to increase human resources in national development, changes in education occur periodically following the times. Education is an ongoing process that aims to increase the quality of human resources. Formal education in Indonesia starts from primary education, secondary education and tertiary education [3].

In order to improve the quality of human resources that are able to compete in millennial times such as the current need for fundamental changes in the community, namely the formation of character which is the basis of the process of change and development in national development, character education helps students not only become smart but also be good [4]. According to [5], the purpose of education is for the intellectual life of the nation. With the existence of character, education can help the development of potential and attitudes in children in achieving educational goals.

Humans as social creatures certainly have different behavior in communication. This is what makes the birth of a branch of psychology. According to [6], psychology is a field of science and applied science that studies human behavior and mental functions scientifically. As a very important role in the world of education, psychology in education is often referred to as educational psychology $[6,7,8,9]$. According to $[10,11]$, educational psychology can be interpreted as Science that investigates and discusses human behavior related to education. Behavior that will be experienced in educational psychology leads to attitudes held by students themselves. The attitude of students in the educational environment becomes very 
important, wherewith these education students can behave well and change their behavior.

Psychology in students' persistence is one form of students' behavior towards activities that are done in earnest without tiring or stopping before work targets are achieved and always prioritizing or paying attention to the satisfaction of the results in every activity undertaken by students $[12,13,14]$. Students can take advantage of optimal time so that sometimes they do not recognize the time, distance, and difficulties they face [15]. In the very enthusiasm and persistence of students, to achieve good results and maximum creativity will arise in each student. Psychology in students' creativity is that students are able to generate new ideas and not easily give up in solving a problem $[16,17,18]$. To foster creativity, education needs to do more than transfer information from teacher to student $[18,19]$. In this case, students must already have high learning creativity so that students can easily gain an understanding of learning science. In the tolerance variable, psychology is also used as a view of religious maturity. The psychological concept of religious maturity is very relevant as a life concept of tolerance including religious tolerance. This concept deserves the attention of religious leaders and educators as a psychological concept related to the principle of tolerant life in an effort to prevent conflict and efforts to continually build peace $[20,21]$.

Character building can be done through a learning process that can be obtained from an educational institution. One of the educational institutions related to character building with junior high school is related to the time students are facing the future from children to adulthood where students have started to think and are moving for life.

One of the subjects that require freedom of concept is natural science because science is classified as abstract and difficult to understand with nature that is complicated by conceptual thinking that can help students improve their ability to use natural science subjects. Natural Sciences is a learning process that is closely related to the environment and order of the universe created by the almighty God $[22,23]$. However, after all, it is necessary for the concept of science participants in students not only to make students only memorize the concept of science, because the desired goal is that students are able to understand the concept of science related to participants who are supported by competent students to help research for natural science subjects, they can discuss science topics without having a look at textbooks containing natural science material, students must be able to understand the concept of science. Scientific attitude is the most important aspect as the focus during the experiment, scientific attitude can shape students' minds critically, the importance of the scientific attitude that students must have is to gain knowledge in various fields because without a positive scientific attitude, students tend to only be reminders of scientific concepts. In addition, the lack of a positive science attitude can also lead to a tendency to try to solve scientific problems in accordance with textbooks, regardless of the behavior of the natural environment which is the context of their science learning $[24,25]$.

Learners must be directly involved in the science learning process to understand the concepts of science well. However, not all students want to be directly involved and feel happy in the process, in the learning process there must be a positive attitude from students so that it causes a sense of pleasure in participating in the science learning activities, more importantly, they suggested that conscious learning is associated with a favorable attitude toward the lesson. Enjoyment in learning is the emotional expression of students intrinsically linked to students' motivation to learn, with learning and school performance at school [26,27]. If students have a negative attitude towards science, it will lead to an attitude that tends to be lazy and not motivated to participate in science learning, students will be sleepy, and not have a strong commitment to learning science, they also do not like physics courses and physics teachers. Based on this premise, various studies have been conducted to determine attitudes in science $[28,29]$. The reaction that arises when students have a positive attitude to natural science subjects will feel that natural science subjects are important and arouse high curiosity about natural science subjects. This will be inversely proportional to students who have negative attitudes to natural science subjects, feeling quickly bored, lazy and not care when science learning is ongoing.

Besides instilling a positive attitude in students, it is also necessary to instill character values. In the 2013 curriculum, there are 17 characters that must be instilled in students, three of which are persistence, creativity, and tolerance. Persistence is an activity that is done in earnest without tiring or stopping before the work target is reached and always prioritizes or pays attention to the satisfaction of the results in every activity carried out [30]. This means that persistence is an effort made in earnest to get optimal results. Students who are persistent in the learning process will always be disciplined in completing their assignments besides that when getting an obstacle when solving problems, students will not easily give up but will try as much as possible to find solutions to their problems.

According to [31], creativity involutes a set of attributes (like self-confidence desire for achievement, sensitivity) and thinking skills (like fluency, mental flexibility, imagination. Creativity is one's ability to discover new things that do not yet exist, with the learning creativity of students in science subjects helping students solve and provide solutions to a problem with new ideas or ideas. Creativity is a person's ability to give birth to something new or a combination of things that already exist until it 
seems new [32]. A strong desire and motivation will make students able to be creative in learning and help increase students' understanding of natural science subjects. Students who have the ability to think creatively will find many ways in which he solves solutions to problems faced in the surrounding environment [33]. So knowing the level of students' creativity is very necessary for learning science. Because students who have a high level of creativity will find it easier to understand concepts in natural science subjects that require deep understanding and can solve difficult problems, while tolerance is a sense of mutual respect in dealing with differences that exist in each human being such as differences in religion, ethnicity and ethnic culture.

Tolerance of Latin tolerant, meaning leniency, tenderness, relief and patience [34] General terms, open terms, grace, willingness and tenderness [35]. In connection with the opinion of [36], it discusses the basic elements needed to foster mutual understanding and debate the differences, as well as being an entry point for the realization of dialogue and harmony among religious believers in the community with the conception of tolerance as respect and appreciation for differences, and a thin model of tolerance as patience [37]. Tolerance is an active attitude to foster mutual respect [25]. Characters can be used as social interactions carried out in the community. The free character becomes the main focus in education to grow this character. With this character taken, it makes students more respectful of a difference that can facilitate social well. According to [38], tolerance is the right form of social interaction.

The purpose of this study was to determine the relationship between Attitude, Persistence, Creativity and Student Tolerance on Natural Science subjects in Junior High School in Muaro Jambi, Junior High School in Jambi City, and Junior High School in Batanghari. In this study the questions addressed are:

1. What is the relationship between Attitude, Persistence, Creativity and Tolerance in Natural Sciences at Middle Schools in Muaro Jambi Regency

2. What is the relationship between Attitude, Persistence, Creativity, and Tolerance in Natural Sciences at Junior High Schools in Jambi City

3. How is the relationship between Attitude, Persistence, Creativity, and Tolerance in Natural Sciences in Batanghari Middle School

Therefore, by knowing the relationship between attitudes, Persistence, Creativity, and Tolerance, it can provide experience for science teachers in the learning process, the teacher can find out the level of Persistence, Creativity, and Tolerance that each student has, making it easier for teachers to prepare or plan learning designs such as strategies, methods or models or media what teachers need to prepare in an effort to help students better understand science subjects.

\section{Materials and Methods}

The research design used is a type of quantitative research associated with correlational design. Correlation measures relationships in terms of how strong a linear relationship is [39]. This study aims to determine the relationship between attitudes towards the variables that have been mentioned based on established standards. In correlational data, the correlation coefficient is used as a measure of the effect in relation to the detail of the direction association [40]. Then this study will measure the relationship between attitudes toward persistence, creativity, and tolerance in natural science subjects in Muaro Jambi State Junior High School, Batanghari State Junior High School, and Jambi City Junior High School. The sampling technique used is total sampling. This was done because the researcher wanted to see the relationship between attitudes, persistence, creativity, and tolerance of all students in natural science subjects in Jambi Muaro Middle School, Batanghari Regency and Jambi City Middle School with the number of samples to fill in the questionnaire as a total collection technique. With a sample of 767 students, the research instrument used was a questionnaire. The questionnaire used was a closed questionnaire. Respondents must choose from the set of answers given. These who tend to be answered quickly, are easily coded, and do not require specific writing skills from the respondent. However, they limit the range of possible answers [41]. The instrument used was the adoption of various studies. The persistence questionnaire was adopted from the study [42] with Cronbach's alpha 0.80 and [43] with 30 questions consisting of 25 positive results and 5 negative results. The creativity questionnaire was adopted from research [44] with Cronbach alpha 0.977, research [45] with a Cronbach alpha of 0.753 with 31 negative statements. subsequently, the tolerance questionnaire was adopted [46] with Cronbach's alpha 0.777 with 32 questions consisting of 28 positive statements and 4 negative statements.

Analysis of the data used in this research is descriptive statistics and inferential statistics. Descriptive statistics used are mean, median, and mode. While the inferential statistics used are through the product-moment correlation test. The results of the product-moment correlation analysis will obtain a correlation coefficient of (r) which is then to determine the strengths of the relationships between these variables which will be seen through the categories below [47]. All data analysis techniques used are assisted with the IBM SPSS Statistics 22.0 program.

Table 1. Correlation Coefficient Category

\begin{tabular}{|c|c|}
\hline Range & Category \\
\hline $0-0,199$ & Very weak \\
\hline $0,20-0,399$ & Weak \\
\hline $0,40-0,599$ & Sufficient \\
\hline $0,60-0,799$ & Strong \\
\hline $0,80-10$ & Very Strong \\
\hline
\end{tabular}




\section{Results}

The novelty of this study is that there are variables used in the study to see the relationship between the variables of science attitude, perseverance, creativity, and tolerance of students in junior high schools in Muaro Jambi, junior high schools in Jambi City, and Batanghari junior high schools. An attitude is a form of a person's perception of object that is described by the expression of like or not [48, $49,50]$. The attitude of these students can be seen from the attitude indicators which include social implications on science, investigation of science, pleasure in learning science, adoption of scientific attitudes to career interests in the field of science, interest in increasing the learning time of science. Like or dislike attitude toward science subjects leads to the impact of students' knowledge itself, how students apply it into everyday life. Furthermore, according to [51,52], persistence is a behavior that shows earnest effort in overcoming various learning barriers and tasks and completing tasks as well as possible. For persistent variables, what can be seen in the indicator include never give up, always focus on the lesson, do the task on time, try to complete the task, creating a good learning atmosphere. Then in the variable of creativity, experts argue that Creativity is the ability to generate new ideas, solve problems, and come up with ideas that have the intentions and goals being said, while creative is a trait possessed by someone who has creativity. Creativity is only owned by creative people $[53,54]$. This variable can be seen through indicators of creativity which include giving ideas, asking questions, fluent in expressing ideas verbally and in writing, do not experience difficulties when faced with a problem, happy with challenging things. In the tolerance variable, experts argue that tolerance is a willingness to respect and allow the establishment, belief, and actions of someone who is different or contrary to what they have without sacrificing the beliefs they hold [55; Dhan, 2017]. In this variable can be seen from the indicators of tolerance which include, peace, respect for differences, and awareness

The novelty of this study is that there are variables that are used in research to see the relationship between the variables of science attitudes, persistence, creativity, and tolerance of students in Junior High School in Muaro Jambi, Junior High School in Jambi City, and Junior High School Batanghari.

\subsection{Description of Attitude, Persistence, Creativity, and Tolerance}

For the description of attitudes, persistence, creativity, and assessment can be seen in the table below:

Table 2. Description of Attitude, Persistence, Creativity, and Tolerance toward Natural Science in Muaro Jambi Regency

\begin{tabular}{|c|c|c|c|c|c|c|}
\hline Variable & Interval & Category & Frequency & $\%$ & Min & Max \\
\hline \multirow{5}{*}{ Attitude } & $54,0-97,2$ & Very not Good & 0 & 0 & \multirow{6}{*}{157,0} & \multirow{6}{*}{252,0} \\
\hline & $97,3-140,4$ & Not Good & 0 & 0 & & \\
\hline & $140,5-183,6$ & Enough & 65 & 28,6 & & \\
\hline & $183,7-226,8$ & Good & 149 & 65,6 & & \\
\hline & $226,9-270,0$ & Very Good & 13 & 5,7 & & \\
\hline \multicolumn{3}{|c|}{ Total } & & 100 & & \\
\hline \multirow{5}{*}{ Persistence } & $30,0-54,0$ & Very not Good & 0 & 0 & \multirow{6}{*}{70,0} & \multirow{6}{*}{144,0} \\
\hline & $54,1-78,0$ & Not Good & 7 & 3,1 & & \\
\hline & $78,1-102,0$ & Enough & 36 & 15,9 & & \\
\hline & $102,1-126,0$ & Good & 124 & 54,6 & & \\
\hline & $126,1-150,0$ & Very Good & 60 & 26,4 & & \\
\hline \multicolumn{3}{|c|}{ Total } & & 100 & & \\
\hline \multirow{5}{*}{ Creativity } & $31,0-55,8$ & Very not Good & 0 & 0 & \multirow{6}{*}{67,0} & \multirow{6}{*}{146,0} \\
\hline & $55,9-80,6$ & Not Good & 4 & 1,8 & & \\
\hline & $80,7-105,4$ & Enough & 39 & 17,2 & & \\
\hline & $105,5-130,2$ & Good & 161 & 70,9 & & \\
\hline & $130,3-155,0$ & Very Good & 23 & 10,1 & & \\
\hline \multicolumn{3}{|c|}{ Total } & & 100 & & \\
\hline \multirow{5}{*}{ Tolerance } & $32,0-57,6$ & Very not Good & 1 & 0,4 & \multirow{6}{*}{56,0} & \multirow{6}{*}{155,0} \\
\hline & $57,7-83,2$ & Not Good & 4 & 1,8 & & \\
\hline & $83,3-108,8$ & Enough & 30 & 13,2 & & \\
\hline & $108,9-134,4$ & Good & 135 & 59,5 & & \\
\hline & $134,5-160,0$ & Very Good & 57 & 25,1 & & \\
\hline \multicolumn{3}{|c|}{ Total } & & 100 & & \\
\hline
\end{tabular}


From Table 2 it can be seen that the description of Attitudes, Persistence, Creativity and Tolerance of students in natural science subjects in Muaro Jambi Regency can be seen from the students' responses to the attitude variable with a Very Poor category of $0 \%$ (0 of 227 students), then for the No category Good as much as $0 \%$ ( 0 of 227 students), then for the Fair Good category as much as $28.6 \%$ (65 of 227 students) while for the Good category as much as $65.6 \%$ (149 of 227 students), and for the Very Good category as much as 5, 7\% (13 out of 227 students). Based on the results of the analysis of the data obtained, it shows that the attitude of students in natural science subjects in Muaro Jambi Regency is Dominant Good.In the persistence variable with the Very Poor category as much as $0 \%$ ( 0 out of 227 students), then for the Not Good category as much as 3.1\% (7 of 227 students), then for the Pretty Good category as much as $15.9 \%$ (36 of 227 students) while for the Good category were $54.6 \%$ (124 out of 227 students), and for the Very Good category as many as $26.4 \%$ (60 out of 227 students). Based on the results of the analysis of the data obtained, it shows that the persistence of students in natural science subjects in Muaro Jambi Regency is Dominant Good.

In the creativity variable is with a Very Poor category as much as $0 \%$ ( 0 out of 227 students), then for the Not Good category as much as $1.8 \%$ (4 out of 227 students), then for the Pretty Good category as much as $70.9 \%$ (161 out of 227 students) while for the Good category were $54.6 \%$ (124 out of 227 students), and for the Very Good category as many as $10.1 \%$ (23 out of 227 students). Based on the results of the analysis of the data obtained, it shows that student creativity in natural science subjects in Muaro Jambi Regency is Dominant Good

In the Tolerance variable is with the Very Poor category as much as $0.4 \%$ ( 1 of 227 students), then for the Not Good category as much as $1.8 \%$ (4 of 227 students), then for the Fairly Good category as much as $13.2 \%$ (30 of 227 students) while for the Good category were $59.5 \%$ (135 of 227 students), and for the Very Good category as many as $25.1 \%$ ( 57 of 227 students). Based on the results of the analysis of the data obtained, it shows that the tolerance of students in natural science subjects in Muaro Jambi Regency is Dominant Good.

Table 3. Descriptions of attitude, persistence, creativity, and tolerance toward Natural Science in Jambi City Junior High Schools

\begin{tabular}{|c|c|c|c|c|c|c|}
\hline Variable & Interval & Category & Frequency & $\%$ & Min & Max \\
\hline \multirow{5}{*}{ Attitude } & $54,0-97,2$ & Very not Good & 0 & 0 & \multirow{6}{*}{134,0} & \multirow{6}{*}{235,0} \\
\hline & $97,3-140,4$ & Not Good & 4 & 1,1 & & \\
\hline & $140,5-183,6$ & Enough & 268 & 70,5 & & \\
\hline & $183,7-226,8$ & Good & 105 & 27,6 & & \\
\hline & $226,9-270,0$ & Very Good & 3 & 0,8 & & \\
\hline \multicolumn{3}{|c|}{ Total } & & 100 & & \\
\hline \multirow{5}{*}{ Persistence } & $30,0-54,0$ & Very not Good & 0 & 0 & \multirow{6}{*}{71,0} & \multirow{6}{*}{149,0} \\
\hline & $54,1-78,0$ & Not Good & 2 & 0,5 & & \\
\hline & $78,1-102,0$ & Enough & 79 & 20.8 & & \\
\hline & $102,1-126,0$ & Good & 234 & 61,6 & & \\
\hline & $126,1-150,0$ & Very Good & 65 & 17,1 & & \\
\hline \multicolumn{3}{|c|}{ TOT } & & 100 & & \\
\hline \multirow{5}{*}{ Creativity } & $31,0-55,8$ & Very not Good & 0 & 0 & \multirow{6}{*}{79,0} & \multirow{6}{*}{139,0} \\
\hline & $55,9-80,6$ & Not Good & 2 & 5 & & \\
\hline & $80,7-105,4$ & Enough & 187 & 49,2 & & \\
\hline & $105,5-130,2$ & Good & 185 & 48,7 & & \\
\hline & $130,3-155,0$ & Very Good & 6 & 1,6 & & \\
\hline \multicolumn{3}{|c|}{ Total } & & 100 & & \\
\hline \multirow{5}{*}{ Tolerance } & $32,0-57,6$ & Very not Good & 0 & 0 & \multirow{6}{*}{76,0} & \multirow{6}{*}{188,0} \\
\hline & $57,7-83,2$ & Not Good & 2 & 0,5 & & \\
\hline & $83,3-108,8$ & Enough & 47 & 12,4 & & \\
\hline & $108,9-134,4$ & Good & 247 & 65,0 & & \\
\hline & $134,5-160,0$ & Very Good & 82 & 21,6 & & \\
\hline \multicolumn{3}{|c|}{ Total } & & 100 & & \\
\hline
\end{tabular}


From Table 3 it can be seen that the description of Attitudes, Persistence, Creativity and Tolerance of students in natural science subjects in the city of Jambi can be seen from the students' responses to the attitude variable with a Very Poor category of $0 \%$ ( 0 of 380 students), then for the Not Good category as much as $1.1 \%$ (4 out of 380 students), then for the Fair Good category as much as $70.5 \%$ (268 out of 380 students) while for the Good category as much as $27.6 \%$ (105 out of 380 students), and for the Very Good category as much as $0.88 \%$ ( 3 out of 380 students). Based on the results of the analysis of the data obtained, it shows that the attitude of students in natural science subjects in the city of Jambi is quite good.

In the persistence variable is with the Very Poor category as much as $0 \%$ ( 0 out of 380 students), then for the Not Good category as much as $0.5 \%$ (2 of 380 students), then for the Pretty Good category as much as $20.8 \%$ (79 out of 380 students) while for the Good category were $61.6 \%$ (234 out of 380 students), and for the Very Good category as many as $17.1 \%$ (65 out of 380 students). Based on the results of the analysis of the data obtained, it shows that the persistence of students in natural science subjects in the city of Jambi is dominantly good.

In the creativity variable is with a Very Poor category as much as $0 \%$ ( 0 out of 380 students), then for the Not Good category as much as $0.5 \%$ (2 out of 380 students), then for the Pretty Good category as much as $49.2 \%$ (187 out of 380 students) while for the Good category were $48.7 \%$ ( 185 out of 380 students), and for the Very Good category as many as $1.6 \%$ (6 out of 380 students). Based on the results of the analysis of the data obtained, it shows that the creativity of students in natural science subjects in the city of Jambi is quite good.

In the Tolerance variable is with the Very Poor category as much as $0.4 \%$ ( 1 of 380 students), then for the Not Good category as much as $0.5 \%$ ( 2 of 380 students), then for the Good Enough category as much as $12.4 \%$ (47 of 380 students) while for the Good category were $65.0 \%$ (247 out of 380 students), and for the Very Good category as many as $21.6 \%$ ( 82 out of 380 students). Based on the results of data analysis obtained, it shows that student tolerance in natural science subjects in the city of Jambi is dominantly good.

Table 4. Descriptions of attitude, persistence, creativity, and tolerance toward Natural Science in Junior High Scchool in Batanghari Regency

\begin{tabular}{|c|c|c|c|c|c|c|}
\hline Variable & Interval & Category & Frequency & $\%$ & Min & Max \\
\hline \multirow{5}{*}{ Attitude } & $54,0-97,2$ & Very not Good & 0 & 0 & \multirow{6}{*}{141,0} & \multirow{6}{*}{250,0} \\
\hline & $97,3-140,4$ & Not Good & 0 & 0 & & \\
\hline & $140,5-183,6$ & Enough & 67 & 41,9 & & \\
\hline & $183,7-226,8$ & Good & 89 & 55,6 & & \\
\hline & $226,9-270,0$ & Very Good & & 2,5 & & \\
\hline \multicolumn{3}{|c|}{ TOT } & & 100 & & \\
\hline \multirow{5}{*}{ Persistence } & $30,0-54,0$ & Very not Good & 0 & 0 & \multirow{6}{*}{82,0} & \multirow{6}{*}{145,0} \\
\hline & $54,1-78,0$ & Not Good & 0 & 0 & & \\
\hline & $78,1-102,0$ & Enough & 18 & 11,3 & & \\
\hline & $102,1-126,0$ & Good & 98 & 61,3 & & \\
\hline & $126,1-150,0$ & Very Good & 44 & 27,5 & & \\
\hline \multicolumn{3}{|c|}{ TOT } & & 100 & & \\
\hline \multirow{5}{*}{ Creativity } & $31,0-55,8$ & Very not Good & 0 & 0 & \multirow{6}{*}{68,0} & \multirow{6}{*}{146,0} \\
\hline & $55,9-80,6$ & Not Good & 2 & 1,3 & & \\
\hline & $80,7-105,4$ & Enough & 70 & 43,8 & & \\
\hline & $105,5-130,2$ & Good & 75 & 46,9 & & \\
\hline & $130,3-155,0$ & Very Good & 13 & 8,1 & & \\
\hline \multicolumn{3}{|c|}{ TOT } & & 100 & & \\
\hline \multirow{5}{*}{ Tolerance } & $32,0-57,6$ & Very not Good & 2 & 1,3 & \multirow{6}{*}{44,0} & \multirow{6}{*}{155,0} \\
\hline & $57,7-83,2$ & Not Good & 2 & 1,3 & & \\
\hline & $83,3-108,8$ & Enough & 11 & 6,9 & & \\
\hline & $108,9-134,4$ & Good & 116 & 72,5 & & \\
\hline & $134,5-160,0$ & Very Good & 29 & 18,1 & & \\
\hline \multicolumn{3}{|c|}{ TOT } & & 100 & & \\
\hline
\end{tabular}


From Table 4 it can be seen that the description of Attitudes, persistence, Creativity and Tolerance of students in natural science subjects in Batanghari Regency can be seen from the students' responses to the attitude variable with a Very Poor category of $0 \%$ ( 0 of 160 students), then for the Not Good category as much as $0 \%$ ( 0 of 160 students), then for the Fair Good category as much as $41.9 \%$ (67 of 160 students) while for the Good category as much as $55.6 \%$ ( 89 of 160 students), and for the Very Good category as much as 2, 5\% (4 out of 160 students). Based on the results of the analysis of the data obtained, it shows that the attitude of students in natural science subjects in Batanghari Regency is Dominant Good.

In the persistence variable is with the Very Poor category as much as $0 \%$ ( 0 out of 160 students), then for the Not Good category as much as $0 \%$ (0 out of 160 students), then for the Pretty Good category as much as $11.3 \%$ (18 out of 160 students) while for the Good category it was $61.3 \%$ (98 out of 160 students), and for the Very Good category it was $27.5 \%$ (44 out of 160 students). Based on the results of the analysis of the data obtained, it shows that the persistence of students in natural science subjects in the city of Jambi is dominantly good.

In the creativity variable is with a Very Poor category as much as $0 \%$ ( 0 out of 160 students), then for the Not Good category as much as $1.3 \%$ (2 out of 160 students), then for the Pretty Good category as much as $43.8 \%$ (70 out of 160 students) while for the Good category it was $46.9 \%$ ( 75 out of 160 students), and for the Very Good category it was $8.1 \%$ (13 out of 160 students). Based on the results of the analysis of the data obtained, it shows that the creativity of students in natural science subjects in Batanghari Regency is dominantly good.

In the Tolerance variable is with the category of Very Not Good as much as $1.3 \%$ ( 2 of 160 students), then for the category of Not Good as much as $1.3 \%$ (2 of 160 students), then for the category of Pretty Good as much as $6.9 \%$ (11 of 160 students) while for the Good category were $72.5 \%$ (116 out of 160 students), and for the Very Good category as many as $18.1 \%$ (29 out of 160 students). Based on the results of the analysis of the data obtained, it shows that the tolerance of students in natural science subjects in Batanghari Regency is dominantly good.

\subsection{Results Correlation Test}

The results of the correlation of attitude, persistence, creativity, and assessment can be seen in the table 5 .

Table 5 shows the correlation between attitude and persistence by 0.493 with a sig value of 0.31 and attitudes of creativity of 0.548 with a sig value of 0.47 . Then the attitude and tolerance of 0.070 with a sig value of 0.24 . These results indicate that the correlation between attitude and persistence, attitude and creativity, and attitude and tolerance in junior high schools in Muaro Jambi Regency are in the sufficient category.

Table 5. Correlation Test Results of Persistence, Creativity, and Tolerance toward Natural Science Subjects in Muaro Jambi Regency

\begin{tabular}{|c|c|c|c|c|c|}
\hline \multicolumn{2}{|c|}{} & Attitude & Persistence & Creativity & Tolerance \\
\hline \multirow{3}{*}{ Attitude } & Pearson Correlation & 1 & .493 & .548 & .470 \\
\cline { 2 - 6 } & Sig. (2-tailed) & & .031 & .047 & .024 \\
\cline { 2 - 6 } & $\mathrm{N}$ & 227 & 227 & 227 & 227 \\
\hline \multirow{4}{*}{ Persistence } & Pearson Correlation & .493 & 1 & $.405^{* *}$ & $.535^{* *}$ \\
\cline { 2 - 6 } & Sig. (2-tailed) & .031 & & .000 & .000 \\
\cline { 2 - 6 } & $\mathrm{N}$ & 227 & 227 & 227 & 227 \\
\hline \multirow{3}{*}{ Creativity } & Pearson Correlation & .548 & $.405^{* *}$ & 1 & $.575^{* *}$ \\
\cline { 2 - 6 } & Sig. (2-tailed) & .047 & .000 & & .000 \\
\cline { 2 - 6 } & N & 227 & 227 & 227 & 227 \\
\hline \multirow{3}{*}{ Tolerance } & Pearson Correlation & .470 & $.535^{* *}$ & $.575^{* *}$ & 1 \\
\cline { 2 - 6 } & Sig. (2-tailed) & .024 & .000 & .000 & 227 \\
\hline
\end{tabular}


The Relationship among Students' Attitudes, Persistence, Creativity, and Tolerance toward Natural Science Subjects

Table 6. Results of Correlation Tests of Attitude, persistence, Creativity, and Tolerance toward Natural Sciences in Junior High Schools in Jambi City

\begin{tabular}{|c|c|c|c|c|c|}
\hline & & Attitude & Persistence & Creativity & Tolerance \\
\hline \multirow{3}{*}{ Attitude } & Pearson Correlation & 1 & .670 & .668 & .613 \\
\hline & Sig. (2-tailed) & & .029 & .037 & .019 \\
\hline & $\mathrm{N}$ & 380 & 380 & 380 & 380 \\
\hline \multirow{3}{*}{ Persistence } & Pearson Correlation & .670 & 1 & $.648^{* *}$ & .635 \\
\hline & Sig. (2-tailed) & .029 & & .000 & .000 \\
\hline & $\mathrm{N}$ & 380 & 380 & 380 & 380 \\
\hline \multirow{3}{*}{ Creativity } & Pearson Correlation & .668 & $.648^{* *}$ & 1 & $.688^{* *}$ \\
\hline & Sig. (2-tailed) & .037 & .000 & .000 & \\
\hline & $\mathrm{N}$ & 380 & 380 & 380 & 380 \\
\hline \multirow{3}{*}{ Tolerance } & Pearson Correlation & .613 & .635 & $.688^{* *}$ & 1 \\
\hline & Sig. (2-tailed) & .019 & .000 & .000 & \\
\hline & $\mathrm{N}$ & 380 & 380 & 380 & 380 \\
\hline
\end{tabular}

Table 7. Results of Correlation Test Attitude, Persistence, Creativity, and Tolerance toward Natural Sciences in Junior High School in Batanghari Regency

\begin{tabular}{|c|c|c|c|c|c|}
\hline & & Attitude & Persistence & Creativity & Tolerance \\
\hline \multirow{3}{*}{ Attitude } & Pearson Correlation & 1 & .530 & $.568^{* *}$ & .573 \\
\hline & Sig. (2-tailed) & & .030 & .040 & .022 \\
\hline & $\mathrm{N}$ & 160 & 160 & 160 & 160 \\
\hline \multirow{3}{*}{ Persistence } & Pearson Correlation & .530 & 1 & .537 & .575 \\
\hline & Sig. (2-tailed) & .030 & & .000 & .000 \\
\hline & $\mathrm{N}$ & 160 & 160 & 160 & 160 \\
\hline \multirow{3}{*}{ Creativity } & Pearson Correlation & $.568^{* *}$ & .537 & 1 & .588 \\
\hline & Sig. (2-tailed) & .040 & .000 & & .000 \\
\hline & $\mathrm{N}$ & 160 & 160 & 160 & 160 \\
\hline \multirow{3}{*}{ Tolerance } & Pearson Correlation & .573 & .575 & .588 & 1 \\
\hline & Sig. (2-tailed) & .022 & .000 & .000 & \\
\hline & $\mathrm{N}$ & 160 & 160 & 160 & 160 \\
\hline
\end{tabular}

Table 6 shows the correlation between attitude and persistence by 0.670 with a sig value of 0.29 attitudes and creativity by 0.668 with a sig value of 0.37 . Then the attitude and tolerance of 0.613 with a sig value of 0.19 . These results indicate that the correlation between attitude and persistence, attitude and creativity, and attitude and tolerance in junior high schools in Jambi City are in the Strong category.

Table 7 shows the correlation between attitude and persistence by 0.530 with a sig value of 0.30 and attitude of creativity by 0.568 with a sig value of 0.40 . Then attitude and tolerance are 0.573 with a sig value of 0.22 . These results indicate that the correlation between attitude and persistence, attitude and creativity, and attitude and tolerance in SMP in Batanghari Regency are in the sufficient category.

\section{Discussion}

Based on the problems reviewed from the research objectives, that is to find out the relationship between attitude, persistence, creativity, and tolerance of natural science subjects in Jambi Province, namely Muaro Jambi Regency, Jambi City, and Batanghari Regency. From data analysis using SPSS, it shows the relationship of some of these variables.

\subsection{The Relationship among Students' Attitudes, Persistence, Creativity and Tolerance toward Natural Science Subject in Muaro Jambi Regency}

The results of the analysis of the data in Table 5 shows that there is enough relationship between attitude, persistence, creativity, and tolerance. This can be seen in the Sig (2-tailed) value which shows the value of attitude, persistence, creativity, and tolerance $<0.05$. A positive attitude must be instilled in students. Students' attitudes will be formed from the social attitudes they have. Social attitudes can be formed from social interactions. This can occur due to several factors seen from the questionnaire 
statements answered by students at junior high schools throughout Muaro Jambi, which have a dominant curiosity towards natural science curiosity that is central to education and learning [57]. Curiosity encourages students to continually try to find out everything related to science by themselves without orders or assignments from the teacher. This shows that students have a good persistence attitude towards natural science subjects. Then the enthusiasm of students is high when there are new ideas related to science. Indonesian students are smart to memorize things but lack the skills to apply their knowledge to solve problems. Maybe related to the tendency to use memory is as a science mastery platform, not thinking kills [58]. If students feel happy about science lessons, then they will be eager to follow science learning if students can provide new ideas during the science learning process, it means that students have a good attitude of learning creativity towards natural science subjects. Students who have a good level of creativity will find it easier to understand natural science subjects. The existence of creativity can help students in achieving learning goals.

There are several factors that can affect students' creativity, namely IQ, students' learning interest, parents, teachers, home and school environment [59]. So that teachers and parents play an important role in developing students' level of creativity in learning so they can maximize and be able to benefit students in solving problems related to science. In addition, students also need to interact with good friends and teachers. It was stated that interactions with peers and their teachers were the main source of happiness for them [60]. If students can interact well with teachers and peers, it means that students already have a good tolerance for natural science subjects. Based on data and facts as well as observations made by researchers, the results of this study are in line with the theory which states that one of the internal factors that can improve learning achievement is learning attitude [61]. The growth of tolerance character is strongly influenced by the attitudes possessed by students. According to [62], students' attitudes are important, but it is not only students that play an important role in achieving positive attitudes. According to [63], with character education, every two sides attached to each character will only be explored and taken on the positive side only. Meanwhile, the negative side will be blunt and not develop. For example, a sense of confidence fosters courage, not levity. Teachers or educators as the spearhead of education having a special role in instilling tolerance toward the world of education will be an example for all. This is also in line with the results of table 2 which shows that students in Muaro Jambi Regency are categorized both in terms of attitude, persistence, creativity, and tolerance toward natural science subjects.

\subsection{The Relationship among Students' Attitudes, Persistence, Creativity, and Tolerance toward Natural Science Subject in Jambi City}

The results of the data analysis in Table 6 shows that there is a good relationship between student attitude, persistence, creativity, and tolerance. This can be seen in the Sig (2-tailed) value which shows the value of student attitude, persistence, creativity, and tolerance $<0.05$. This can occur due to several factors seen from the questionnaire statements answered by students at junior high schools in Jambi City dominantly always trying to find books or learning materials for science in the library to enrich students' learning materials [64]. Looking for books that are used as self-study materials in the library can add additional insights related to science subjects outside of the teaching materials that have been given by teachers viewed from students' efforts in enriching knowledge shows that students have a persistence attitude towards science subjects. In addition, when discussing science issues, the majority of students have different responses and come up with new ideas. A classroom discussion is an active teaching technique because it enables students to explore issues of interest, opinions, and ideas [65].

When discussing many opinions that will arise from each individual who is different from these differences, a new idea that can help solve problems in natural science subjects will appear, meaning that students have a good attitude of learning creativity towards natural science subjects. Students with high creativity will be able to learn well because they always have creative ideas that can increase their motivation to learn. Students will also always try to find something new in his life [66]. That way it can be said of students who are able to convey ideas or opinions in a discussion forum means that students have a good level of learning creativity. And despite having different responses, students can respect and respect each other's differences of opinion. Respect is regard for that which is worthy of admiration [67]. By respecting differences of opinion, it is the same as accepting input from others so that if there is a mistake in solving science problems, it can receive input from others. This means that students have a good tolerance toward natural science subjects. This is also in line with the results of table 3 which shows that students at Junior High School in Jambi City are dominantly categorized both in the variables of attitude, persistence, creativity, and tolerance toward natural science subjects. According to [68], tolerance is mutual respect with the goal of peace. According to [69], tolerance is the nature of respecting the stance, opinions, views, beliefs, habits, behaviors that are different from the establishment itself. We can see indicators of tolerances character as well as aspects of peace, respect for differences and individuals. As explained by [46], the character of tolerance is through three aspects, namely peace, respect for differences 
individuals, and awareness.

Persistence, creativity, and tolerance are impulses found in a person to try to change behavior or a better attitude in meeting their needs. So persistence, creativity, and tolerance is an encouragement to achieve good learning achievement.

\subsection{The Relationship among Students' Attitudes, Persistence, Creativity, and Tolerance toward Natural Science Subjects in Batanghari Regency}

The results of the analysis of the data in table 7 show that there is a sufficient relationship between students' attitudes, persistence, creativity, and tolerance. This can be seen in the Sig (2-tailed) value which shows the value of attitude towards persistence, creativity and tolerance $<0.05$. This can occur due to several factors seen from the questionnaire statements that are answered by dominant students always carrying science books when learning science subjects by bringing books, which means that students are ready to follow the lessons and have good persistence attitude toward science subjects, students have burning passion when getting new ideas in science subjects. Passion is learning something new, giving importance. It is constantly being in search of the new and in the effort of learning [70]. When students have a passion when trying to find something new, then students have a good persistence attitude towards science subjects. In addition, students can accept differences of opinion, it can be said that students have a good tolerance attitude towards natural science subjects. This is also in line with the results of table 5 which shows that students in Batanghari Regency are dominantly categorized both in the variable attitude, persistence, creativity, and tolerance toward natural science subjects. This means that the average student at Junior High School throughout Batanghari Regency has a positive attitude in achieving good performance toward natural science subjects.

From the results of data analysis obtained by students in junior high schools in Muaro Jambi District, there is a relationship of attitude, persistence, creativity, and tolerance with the medium category. In contrast to the results of the analysis in Jambi City Middle School and in Batanghari Middle School, they have a strong attitude, persistence, creativity and tolerance relationship. The difference in the level of relationship between attitude, persistence, creativity, and tolerance in the three Regency is caused by factors such as the availability of practical tools, the condition of facilities and infrastructure, teaching staff and other conditions that influence the level of difference in the relationship between attitude, the persistence of creativity and tolerance.

\section{Conclusions}

Based on the results of the research and discussion above, it is concluded that there is a relationship between students' attitudes towards persistence, creativity, and tolerance in natural science subjects in Muaro Jambi Regency Junior High Schools which have a positive relationship with the sufficient category. Then the attitude of students towards persistence, creativity and tolerance in natural science subjects in Jambi City Junior High School has a positive relationship with the strong category. Likewise, the attitude of students towards persistence, creativity and tolerance in natural science subjects in Junior High School in Batanghari Regency has a positive relationship with the strong category.

\section{Acknowledgments}

Thank you to principals of Muaro Jambi Regency public schools, Jambi city public schools, and Batanghari Regency public schools and to the teachers and students who have been asked to be sampled in this study, I thank you

\section{REFERENCES}

[1] D. A. Nafiati. "Motivation, Creativity, and Self Confidence as Forming Factors of Economic Learning Autonomy," Dinamika Pendidikan, Vol 12, No 2, pp. 182-195.2019. DOI: https://doi.org/10.15294/dp.v12i2. 13566.

[2] D. I. Lestari, \& A. K. Projosantoso. "Pengembangan Media Komik IPA Model PBL untuk Meningkatkan Kemampuan Berfikir Analitis dan Sikap Ilmiah," Jurnal Inovasi Pendidikan IPA,Vol. 2. No. 2, pp. 145-155. 2016

[3] Darmaji., D.A. Kurniawan \& A. Suryani. "Effectiveness of Basic Physics II Practicum Guidelines Based On Science Process Skills," Jurnal Ilmu Pendidikan fisika, Vol. 4, No. 1, pp. 1-7. 2018

[4] M. A. Putri \& S. Harto. "Promoting Character Education in Efl Classroom: Using Children' S Literature As a Teaching Material. Vol. 5, No. 2, pp 163-169. 2019

[5] A. Sukasni \& H. Efendy. "The Problematic of Education System in Indonesia and Reform Agenda," International Journal of Education, Vol 9, No. 3, pp. 183.2019. DOI: https://doi.org/10.5296/ije.v9i3.11705.

[6] S. S. Anwar. "Tanggung Jawab Pendidikan Dalam Perspektif Psikologi,"

[7] H. Gleitman. "Psychology (2nd ed.)," New York: Norton. 1986

[8] Zanawi. "Psikologi Pendidikan," Jakarta: Yayasan Kanisius. 1993

[9] S. Sauri. "Membangun karakter bangsa melalui pembinaan profesionalisme guru berbasis pendidikan nilai," Jurnal Pendidikan Karakter, Vol. 2 No. 2, pp. 1-15.

[10] S. Padmowihardjo. "Psikologi belajar mengajar," 
[11] Pendidikan, T. P. B. P. (1993). Psikologi Pendidikan. Yogyakarta: UPP UNY.

[12] P. N. Taneo,, H. Suyitno., \& W. Wiyanto. "Kemampuan Pemecahan Masalah Dan Karakter Kerja Keras Melalui Model SAVI Berpendekatan Kontekstual," Unnes Journal of Mathematics Education Research, Vol.4, No. 2. 2015

[13] S. Krashen. "The Hard Work Hypothesis: Is Doing Your Homework Enough to Overcome the Effects of Poverty?" Multicultural education, Vol. 12, No. 4, pp. 16.

[14] C. Masui., J. Broeckmans., S. Doumen., A. Groenen,, \& G. Molenberghs." Do diligent students perform better? Complex relations between student and course characteristics, study time, and academic performance in higher education," Studies in Higher Education, Vol. 39, No. 4, pp. 621-643. 2014

[15] S. Aithal., \& P. S. Aithal, "Student Centric Learning through Planned Hard work-An Innovative Model," International Journal of Scientific Research and Modern Education (IJSRME), Vol. 1, No. 1, pp. 886-896. 2016

[16] N. Farida. "Pengaruh sikap kreatif terhadap prestasi belajar matematika," AKSIOMA: Jurnal Program Studi Pendidikan Matematika, Vol. 3, No. 2. 2014

[17] I. Jahnke., T. Haertel., \& J. Wildt. "Teachers' conceptions of student creativity in higher education," Innovations in Education and Teaching International, Vol. 54, No. 1, pp. 87-95. 2017

[18] Csikszentmihalyi, M., \& Wolfe, R. "New conceptions and research approaches to creativity: Implications of a systems perspective for creativity in education," In The systems model of creativity (pp. 161-184). Springer, Dordrecht. 2014

[19] Soh, K. "Fostering student creativity through teacher behaviors," Thinking Skills and Creativity, 23, 58-66. 2017

[20] Ismail, R, "Konsep Toleransi dalam Psikologi Agama (Tinjauan Kematangan Beragama)," Religi: Jurnal Studi Agama-agama, 8(1), 1-12. 2012

[21] Maimanah, M., "Wanita dan Toleransi Beragama (Analisis Psikologis)," Mu'adalah; Jurnal Studi Gender dan Anak, 1(1). 2013

[22] Jain, V., “3D model of attitude," International Journal of Advanced Research in Management and Social Sciences, 3(3), 1-12. 2014

[23] Susilawati, A., Hernani, H., \& Sinaga, P. "The Application of Project-Based Learning Using Mind Maps to Improve Students' Environmental Attitudes Towards Waste Management in Junior High Schools," International Journal of Education, 9(2), 120. 2017. https://doi.org/10.17509/ije.v9i2.5466.

[24] Zulirfan,et al., "Take-Home-Experiment: Enhancing Students' Scientific Attitude," Journal of Baltic Science Education Vol. 17, No. 5 ISSN 1648-3898. 2018

[25] Kurniawan, D. A., Perdana, R., \& Kurniasari, D.,. "Identification of Student Attitudes toward Physics Learning at Batanghari District High School," The Educational Review, USA, 2(9), 475-484. 2018https://doi.org/10.26855/er.2018.09.003.
[26] Djiwandono, P. I, "The Learning Styles of Millennial Generation in University: a Study in Indonesian Context" International Journal of Education, vol. 10, no. 1, pp. 12. 2017. https://doi.org/10.17509/ije.v10i1.5085.

[27] Manasia, L. "Enjoyment of Learning in Upper Secondary Education. An Exploratory Research," Procedia - Social and Behavioral Sciences, 180 (November 2014), 639-646. 2015 https://doi.org/10.1016/j.sbspro.2015.02.172K.

[28] Astalini., Kurniawan, D. A., \& Putri, A. D. "Identifikasi Sikap Implikasi Sosial Dari Ipa, Ketertarikan Menambah Waktu Belajar Ipa, Dan Ketertarikan Berkarir Dibidang Ipa Siswa Smp Se-Kabupaten Muaro Jambi," Jurnal Tarbiyah, vol. 7, no. 2, pp. 93-108. 2018

[29] Manuel Guido, R. D., "Attitude and Motivation towards Learning Physics," International Journal of Engineering Research \& Technology (IJERT), Vol. 2(July), 2278-0181. 2013 Retrieved from www.ijert.org.

[30] Suhadi, O "Penguatan Pendidikan Karakter (PPK,". Jakarta: Erlangga. 2018

[31] Fieldz, Z., \& Bisschoff, C (2014) Developing and Assessing a Tool to measure The Creativity of University Student. J Soc Sci, 38(1), 23-31

[32] Ngalimun, "Strategi dan Model Pembelajaran," Aswaja Pressindo: Yogyakarta. 2013

[33] Sigit, D. V., Heryanti, E., Pangestika, D., A. W., Ichsan, I. Z. 2019. Pembelajaran

[34] Hornby, A. S., Cowie, A. P., Gimson, A. C., \& Hornby, A. S. "Oxford advanced learner's dictionary of current English," (Vol. 1428). Oxford: Oxford university press. (1974).

[35] Casram, C., "Membangun Sikap Toleransi Beragama dalam Masyarakat Plural," Wawasan: Jurnal Ilmiah Agama Dan Sosial Budaya, 1(2), 187-198. 2016

[36] Bahari., "Toleransi Beragama Mahasiswa," Jakarta: Kementrian Agama RI. 2010

[37] Coleman, E. B., \& White, K., "Religious Tolerance, Education and the Curriculum," Netherlands: Sense Publisher. 2014

[38] Kinloch, Graham C., "Sociological Theory: Development and Major Paradigm," Pustaka Setia: Bandung. 2005

[39] Cohen, H., McCabe, C., Harris, N., Hall, J., Lewis, J., \& Blake, D. R., "Clinical evidence of parietal cortex dysfunction and correlation with extent of allodynia in CRPS type 1," European journal of pain, 17, vol. 4, pp. 527-538. 2013

[40] Cohen, Louis.,Manion.,L.,M.K., Research Methods In Education. Routledge. New York. 2017

[41] Walliman, N. "Research Methods the Basics," Routledge: New York. 2011

[42] Miller, Michael J.,Woehr, D.J., Hudspeth, N. “The Meaning and Measurement of Work Ethic: Construction and Initial Validation of a Multidimensional Inventory," Journal of Vocational Behaviour. Vol. 24, no. 50, pp. 1-39. 2001

[43] Sapulette, Marlyen Sharly., Wardana, A. "Peningkatan 
Karakter Siswa Kelas IV SD Negeri 16 Ambon Melalui Pembelajaran PPKN dengan Media Cerita Rakyat," Harmoni Sosial Jurnal Pendidikan IPS. Vol. 3, no. 2, pp. 150-165. 2016

[44] Ahmad, M. "Hubungan Potensi Akal dengan Kreativitas Belajar Siswa Bidang Studi Pendidikan Agama Islam di SMK Kanada Sakura Indonesia (KANSAI) Pekanbaru," Jurnal Pendidikan Agama Islam Al-Thariqah, vol. 2, no. 1, pp. 51-72. 2017

[45] Khairunnisa,.Wisudawati, A.W. "Pengaruh Model Pembelajaran Treffinger Terhadap Kreativitas Berpikir Kimia pada Peserta Didik Kelas XI di SMAN 1 Sewon" Jurnal Tadris Kimiya. Vol. 3, no. 1, pp. 52-61. 2018 doi: https://doi.org/10.15575/jtk.v3i1.2325

[46] Supriyanto, A., \& Wahyudi, A. (2017). Skala karakter toleransi: konsep dan operasional aspek kedamaian, menghargai perbedaan dan kesadaran individu. Counsellia: Jurnal Bimbingan dan Konseling, vol.7, no. 2, pp. 61-70. 2017

[47] Sugiyono. "Memahami Penelitian Kualitatif," Bandung: Alfabeta. 2007

[48] Astalini, A., Kurniawan, D. A., Melsayanti, R., \& Destianti, A., "Sikap terhadap mata pelajaran ipa di smp se-kabupaten muaro jambi." Lentera Pendidikan: Jurnal Ilmu Tarbiyah dan Keguruan, vol. 21, no. 2, pp. 214-227. 2019

[49] Anwar, H. "Penilaian sikap llmiah dalam pembelajaran sains,” Jurnal Pelangi Ilmu, vol. 2. no. 5. 2009

[50] Zulyan, S. V., Pitoewas, B., \& Adha, M. M. "Pengaruh Keteladanan Guru Terhadap Sikap Belajar Peserta Didik," Jurnal Kultur Demokrasi, vol. 2mo. 2. 2014

[51] Yaumi, M.Hum., M.A, Dr. Muhammad. "Pendidikan Karakter Landasan, Pilar \& Implementasi" Jakarta: Kencana. 2014

[52] Setiawati, N. A. "Pendidikan Karakter Sebagai Pilar Pembentukan Karakter Bangsa" In Prosiding Seminar Nasional Tahunan Fakultas Ilmu Sosial Universitas Negeri Medan. Vol. 1, No. 1, pp. 348-352). 2107

[53] Aini,dkk. Montase Dan Pembelajaran (Montase Sebagai Pembangun Daya Fikir DanKreativitas Anak Usia Dini). Ponorogo : Uwais Inspirasi Indonesia

[54] Insyasiska, D., Zubaidah, S., \& Susilo, H "Pengaruh project based learning terhadap motivasi belajar, kreativitas, kemampuan berpikir kritis, dan kemampuan kognitif siswa pada pembelajaran biologi," Jurnal Pendidikan Biologi, vol.7. no. 1, pp. 9-21. 2017

[55] Maulana, M. A. "Pelaksanaan Toleransi Keberagamaan Dalam Proses Pendidikan Agama Di Geeta School Cirebon. Oasis,” Jurnal Ilmiah Kajian Islam, vol. 1, no. 2. pp. 17-38. 2017

[56] Nurlaeli, I. "Pengaruh Faktor Budaya, Psikologi, Pelayanan, Promosi dan Pengetahuan tentang Produk terhadap Keputusan Nasabah Memilih BPRS di Banyumas," Islamadina: Jurnal Pemikiran Islam, 18(2), 75-106.

[57] Pluck, G., \& Johnshon, H. L. "Stimulating Curiosity to Enhance Learning," Education Science and Psychology, vol. 2 , no. 19 , pp. $24-31.2011$
[58] Putra, M. I. S., \& Widodo, W., \& Jatmiko, B., \& Mudilarto. "The Development of Science Cps (Collaborative Problem Solving) Learning Model to Improve Future Islamic Elementary School Teachers' Collaborative Problem solving Skills and Science Literacy" Unnes Science Education Journal, vol. 7, no. 1, pp. 35-49. 2018

[59] Sunarti., "Meningkatkan Kreativitas Belajar Siswa Dengan Menggunakan Metode Karyawisata Pada Mata Pelajaran Bahasa Indonesia Pokok Bahasan Menulis Karangan Bebas Kelas Iii Sdn 2 Metro Barat Kota Metro T.P 2010/2011," vol 1.no 1. 2016

[60] Al-Shara, I. "Learning and Teaching Between Enjoyment and Boredom As Realized By The Students: a Survey From the Educational Field," European Scientific Journal, vol. 11 , no. 19 , pp. $1857-7881.2015$

[61] Dalyono. "Psikologi Pendidikan,” Jakarta: PT Rineka Cipta. 2014

[62] Hardiyanti, K., Astalini, A., \& Kurniawan, D. A. "Sikap Siswa Terhadap Mata Pelajaran Fisika Di Sma Negeri 5 Muaro Jambi" EduFisika: Jurnal Pendidikan Fisika, vol 3, no. 2, pp. 1-12. 2018

[63] Dewi, E. M. P. (2016). Gambaran Karakter dan Aspirasi terhadap Pendidikan Karakter pada Mahasiswa Psikologi Universitas Negeri Makassar (Unm). INQUIRY: Jurnal Ilmiah Psikologi, vol.7, no. 2. 2016

[64] Slamet, S.Y., \& Winarni, R., \& Ismail, S.M. (2015). The Development of Text Book to Write Story Based on Character Education in Contextual Learning. International Journal on Studies in English Language and Literature (IJSELL), vol. 3, no. 7, pp. 43-50. 2015

[65] Hackathorn, J., \& Solomon, E.D., \& Blankmeyer, K.L. "Learning by Doing: An Empirical Study of Active Teaching Techniques" The Journal of Effective Teaching. Vol. 11, no. 2, pp. 40-54. 2011

[66] Wilda., "Pengaruh Kreativitas Dan Minat Belajar Terhadap Hasil Belajar" 2016

[67] Grady, E.O., \& Hinchion, C., \& Namara, M.M. "The importance of respect in teaching and learning: perspectives of final year pre-service teachers in a regional university in Ireland" European Journal of Teacher Education, vol. 34, no. 4,pp. 501-508. 2011

[68] Widiyanto, D. (2017). "Penanaman Nilai Toleransi Dan Keragaman Melalui Strategi Pembelajaran Tematik Storybook Pada Mata Pelajaran Ppkn Di Sekolah Dasar. Pendidikan Kewarganegaraan," vol. 7, no. 2. 2835. 2017

[69] Suharyanto, A. Peranan Pendidikan Kewarganegaraan Dalam Membina Sikap Toleransi Antar Siswa. vol. 1, no. 2, pp. 192-203.2013

[70] Serin, H. (2017). "The Role of Passion in Learning and Teaching," The Role of Passion in Learning and Teaching, vol.4, no. 10 , pp. 60-64. 2017 